\title{
Kitsch or Visionary?: Charismatic Eschatological Community in Folk Art of the American South
}

\author{
Steven Félix-Jäger \\ Southeastern University, Lakeland, USA
}

\begin{abstract}
Where do we draw the line of divinely inspired visionary art, and Christian kitsch? Folk artists such as the Rev. Howard Finster and Sister Gertrude Morgan straddled the fence of kitsch and visionary art because they created work that was blatantly polemical and didactic, yet lived lives that inspired thousands of people across the US. The so-called "Southern Folk Art" movement consists of self-taught artists from the American South who are self-trained and rely heavily on "visions" and "prophetic words" as the genesis of their art. This article contends that the art produced by folk artists is documentation of their visionary insights as opposed to detached works that are admired for aesthetic reasons. While folk art of the American South portrays the charismatic imagination with themes of eschatological community and the second coming, it is the "visionary artist" that is contemplated, rather than his or her bona fide message of redemption and re-creation.
\end{abstract}

Keywords: Folk Art, Sister Gertrude Morgan, Howard Finster, Visionary Art, Kitsch, American South

In his 1985 essay entitled, "In Search of the Visionary Image,” art critic Donald Kuspit distinguishes between images that are visionary and those that are merely fantastical. He writes,

The vigorous manipulation of sources does not in itself guarantee visionary dimension of impact.... Visionary images take possession of the viewer-they can't easily be shaken off-whereas the viewer easily takes possession of fanciful images. Visionary images seem to epitomize consciousness concentrate it against the viewer's will to give him of her a singular sense of his or her concrete being; whereas fanciful images diffuse being in facile communication. They are easily summed up and have an easy continuity with the everyday imagery from which they derive. ${ }^{1}$

Visionary imagery allows the viewer to transcend this world and come face to face with his or her existential reality. Fanciful imagery, on the other hand, copies or mocks reality in order to offer the viewer a nostalgic sense of escape. Fanciful imagery, is, therefore, only kitsch. Christian art often straddles the fence between kitsch and visionary art. For instance, although William Blake's prints and paintings often literally depict biblical scenes, Blake is renowned as a quintessential and prototypical visionary artist. Whereas the many Jesus paintings that adorn the walls of American churches and Christian bookstores are deemed as kitsch. What criteria differentiate the two? To use Kuspit's formulation, Blake's work causes a sense of transcendence in the viewer, whereas the latter works offer sentimentality.

Steven Félix-Jäger, Ph.D., Adjunct Professor, Southeastern University and Polk State College.

Correspondence concerning this article should be addressed to Steven Félix-Jäger, 1000 Longfellow Blvd., Lakeland, FL 33801.

${ }^{1}$ Donald Kuspit, “In Search of the Visionary Image” Art Journal, Vol. 45, No. 4 (1985), 321. 
How then should we view the art of folk artists like Howard Finster and Sister Gertrude Morgan? Their work often resembles a poorly reproduced chick tract. It is unabashedly literal and polemical, and regularly comes across as judgmental and didactic. Yet the artworld has embraced folk art, deeming Finster and Morgan as some of this genre's superstars. In this article, I will assess the issue of folk art's place in the greater artworld, and contend that the art produced by folk artists is documentation of their visionary insights as opposed to detached works that are admired for aesthetic reasons. While folk art of the American South portrays the charismatic imagination with themes of eschatological community and the second coming, it is the "visionary artist” that is contemplated, rather than his or her bonafide message of redemption and re-creation.

\section{Folk and Outsider Art}

Folk art is, in a way, a sub-category of Outsider Art. According to Colin Rhodes, the term developed in the 1970s as an English equivalent to Jean Debuffet's concept of "Art Brut.”” Art Brut literally means "raw art," and describes the artwork of people that were untouched by the institution of high art. ${ }^{3}$ In other words, Art Brut sought to arrive at primitive and natural human creativity —an endeavor only possible when the artist is untrained and uncorrupted by the institutional world of art. This is the sort of art that is raw and real. While these artists were considered outsiders to high art, they were also outsiders to the dominant strands of their contemporary culture. Rhodes writes, "the artist outsiders are, by definition, fundamentally different to their audience, often thought of as being dysfunctional in respect of the parameters for normality set by the dominant culture." ${ }^{4}$ Only cultural outsiders are separated from the institution enough to display a pure and untainted creativity. Folk art, like the other varieties of Outsider Art, consists of self-taught artists who create art according to their own cultural and religious experiences. While the American South is not the only locale for folk art, it is a hub that facilitates the southern religious climate of conservative evangelicalism and charismatic spirituality. ${ }^{5}$ So while folk artists are not complete outsiders (they exist in their own religious communities and have normal cultural contact), ${ }^{6}$ they are far removed from the establishment, politics, and coerciveness of the artworld.

The charismatic Christianity of the American South has particularly influenced American folk art. According to Leslie Luebbers, the artworks of these folk artists portray the theology of evangelical Christianity and are indispensible for understanding the American South. ${ }^{7}$ Christian folk artists rely heavily on visions and "prophetic words" as the genesis of their art. They create art according to their theological commitments, portraying a proclivity towards eschatological concerns. As many of these artists are involved in the church (some even holding ordination), they display visions of redemption in contemplative, and sometimes, polemical ways. The coming Christ is also an important theme in their art as they hope to inspire conversion in advance of the ensuing tribulation and millennial reign. These folk artists see themselves as prophets carrying out God's mission of reconciliation until the kingdom of God is fully ushered in.

\footnotetext{
${ }^{2}$ Colin Rhodes, Outsider Art: Spontaneous Alternatives (London: Thames \& Hudson, 2000), 7.

3 Lucienne Peiry, Art Brut: The Origins of Outsider Art (Paris: Flammarion, 1997), 39.

${ }^{4}$ Rhodes, 7.

${ }^{5}$ Charles Wilson, “A larger view: Self-taught art, the Bible, and Southern Creativity,” in Coming Home!: Self-Taught Artists, the Bible and the American South, Carol Crown, Ed. (Jackson: University Press of Mississippi, 2004), 82.

${ }^{6}$ Leslie Luebbers, "Introduction," in Coming Home!: Self-Taught Artists, the Bible and the American South, Carol Crown, Ed. (Jackson: University Press of Mississippi, 2004), 12.

7 Leslie Luebbers, "Introduction,” in Coming Home!: Self-Taught Artists, the Bible and the American South, Carol Crown, Ed. (Jackson: The University Press of Mississippi, 2004), 12.
} 
Charismatic faith in the south developed ${ }^{8}$ throughout the 20th century, and particularly through Holiness and Pentecostal streams. These new movements focused on the experience of the Holy Spirit in everyday life, which significantly impacted southern creativity in music and the arts. ${ }^{9}$ Randall Stephens points out, however, that mainstream Christianity and the general populace, tended to look at these renewal movements with disdain. Stephens writes, "In part, because of their strange beliefs, ecstatic worship, marginal social status, and apparent anti-intellectualism, outside observers often dismissed holiness disciples and pentecostals as a dispossessed minority, uneducated and fanatical." ${ }^{10}$ Nevertheless, Holiness and Pentecostal Christianity spread rapidly throughout the 1900s. Stephens claims that it was the Holiness and Pentecostal openness to racial and gender integration that became one of the most distinguishing marks of these traditions. ${ }^{11}$ This openness allowed their meetings to often be "racially integrated, wild, and loud."12

Many early Holiness and Pentecostal adherents held to a premillennial eschatology that viewed the world as growing worse and worse until meeting its cataclysmic demise at the end of the tribulation. ${ }^{13}$ The end would not come about by human endeavors or missionary activity (a view long held by postmillennialists), but would instead come as a fulfillment of history. The greatest sign of the world's impending doom was the apostate church and its growing secularization. ${ }^{14}$ So these dispensational charismatics shifted their orthopraxis from social concern to kerygmatic deliveries. They needed to let the world know of the coming Christ and the impending doom before it was too late. These warnings and proclamations would litter the pages of mass-produced print media, which helped spread the word about this brand of eschatology.

Charismatic evangelicalism, in all its varieties, typically holds to a high view of biblical inspiration and inerrancy. ${ }^{15}$ So the moral absolutism found in southern folk art reflects a literalistic reading of Scripture. Biblical prophecies are also read as promises that God will keep. ${ }^{16}$ Many of these folk artists see themselves as part of the prophetic tradition, and see their work as direct messages from God. For the folk artist, prophecy is the place where bibliology and eschatology meet. God has given specific messages to these visionary outsiders to express and deliver to the masses. Folk artists feel a calling to faithful deliberation of God's warnings, judgments, and salvific messages. While the works of folk artists are typically highly personal, they are also often unabashedly didactic and proselytizing. ${ }^{17}$ This causes one to wonder why these works are not considered

\footnotetext{
${ }^{8}$ It should be noted that neither the Holiness nor Pentecostal movements began in the South. Holiness Christianity gained a southern audience following the postbellum era after originating in the North (Stephens, The Fire Spreads, 16), and Pentecostal teachings began in Kansas with teachings from Charles Parham, but was really set ablaze at the Azusa Street Revival beginning in 1906 under the leadership of William Seymour (227). Holiness and Pentecostal faith and practices, however, did find their way South where they would grow exponentially in adherents and influence.

${ }^{9}$ Wilson, "A Larger View, 75.

10 Randall Stephens, The fire spreads: Holiness and Pentecostalism in the American South (Cambridge: Harvard University Press, 2008), 5.

11 Stephens, 9.

12 Stephens, 9.

13 Stephens, 162. It should be noted here that some scholarship has been done on early documents showing that there was actually much greater diversity in early Pentecostal eschatology. Larry McQueen argues that only the Finished Work and Oneness Pentecostals really latched onto the Darbyian Dispensational Eschatology. See Larry McQueen, Toward a Pentecostal Eschatology: Discerning the Way Forward (Dorset: Deo Publishing, 2012).

14 Stephens, 169.

${ }^{15}$ Carol Crown and Charles Russell, "Introduction,” in Sacred and Profane: Voice and Vision in Southern Self-taught Art, Carol Crown and Charles Russell, Eds. (Jackson: University Press of Mississippi, 2007), xiv.

${ }^{16}$ Carol Crown, "The Bible, Evangelical Christianity, and Southern Self-Taught Artists,” in Coming Home!: Self-Taught Artists, the Bible and the American South, Carol Crown, Ed. (Jackson: University Press of Mississippi, 2004), 15.

17 Crown, “The Bible," 15.
} 
Christian kitsch. Instead, the contemporary artworld puzzlingly accepts these works as legitimate and authentic works of art. Perhaps a closer look at a few of the more successful charismatic southern folk artists will shed some light on this issue.

\section{Morgan and Finster}

Sister Gertrude Morgan was one of the most influential charismatic folk artists. Morgan painted scenes of Revelation, utilizing her art as a ministry tool for a holistic ministry. Morgan was born in Lafayette, Alabama in 1900, and although she spent the first half of her life living and ministering in Alabama and Georgia, she settled in New Orleans in 1939, where she would spend the rest of her life ministering to the folks around the French Quarter. ${ }^{18}$ In New Orleans she established an orphanage and raised money by singing and preaching in the streets. ${ }^{19}$ Eventually she felt a call to illustrate her sermons and so, although untrained, she began to paint pictures. $^{20}$

Common traits among folk artists are complete devotion to their causes or beliefs, and idiosyncratic eccentricities that are portrayed both in their art and personal lives. In the case of Morgan, she was devoted to Christ and his ministry. She often received revelations from the Lord that shaped the direction of her ministry. For instance, it was revealed to her that she was selected to be the bride of Christ, literally. ${ }^{21}$ This caused her to change her usual all-black garb to all-white, symbolizing her marital union with God. ${ }^{22}$ She also saw herself as a spiritual nurse faithfully working for "Dr. Jesus."23 And although she taught from a Holiness and Sanctified perspective, she, like many Southern folk artists, proclaimed her own version of charismatic faith. ${ }^{24}$

Morgan grew to prominence after a local entrepreneur and art dealer named Larry Borenstein discovered her preaching in the French Quarter. ${ }^{25}$ Borernstein invited her to show her art in his gallery and to perform music and ministry. ${ }^{26}$ Shortly thereafter, Borenstein became Morgan’s main benefactor, helping her sell work, and even funding records of her music. ${ }^{27}$ With Borenstein's help, Morgan spent the next 20 years ministering and creating art. She would soon become one of the most well-known and beloved folk artists of the 20th century, and an icon of New Orleans culture.

Morgan's influence was great because of her strength as a woman, as a religious figure, and as an ethnic minority. She had a single-minded devotion to her work and an ardent enthusiasm that was both contagious and at times intimidating, causing artists around the world to draw influence from her. For instance, contemporary artist Leslie Dill displayed an impressive installation entitled Hell Hell Hell, Heaven Heaven Heaven: Encountering Sister Gertrude Morgan and Revelation in 2010 at the Whatcom Museum in Bellingham, Washington. ${ }^{28}$ The installation consists of drawings depicting a juxtaposition of words and images that were

${ }^{18}$ William Fagaly, Tools of Her Ministry: The Art of Sister Gertrude Morgan (New York: Rizzoli International Publications, 2004), 3.

19 Fagaly, 3.

${ }^{20}$ Fagaly, 12.

21 Fagaly, 12.

22 Fagaly, 12.

23 Fagaly, 12.

24 Fagaly, 13.

25 Fagaly, 20.

26 Fagaly, 20.

27 Fagaly, 24.

28 Barbara Matilsky, Leslie Dill's Poetic Visions: from SHIMMER to SISTER GERTRUDE MORGAN (Bellingham: Whatcom Museum, 2011), 7. 
inspired by the book of Revelation. These works pay homage both to Morgan and to the destructions of Hurricane Katrina as they depict a subject of devastation. The drawings surround two mannequins dressed in gowns that are decorated with apocalyptic words. These gowns depict the two stages of Morgan's life as one is black and the other is white. Matilsky writes, "Dill's installation honors not only Sister Gertrude Morgan but the city of New Orleans...the artist views Morgan as a kindred spirit who embraced creativity to communicate personal insight and the affirmation of life." ${ }^{29}$ So in the case of Dill, it is Morgan's approach to life and art, rather than the actual artifacts she created, that inspired her. What the artworld seems to be most intrigued by is Morgan's determined and dedicated spirit.

Perhaps the best-known visionary folk artist is Howard Finster. Finster was a retired Southern Baptist minister, whose numerous artworks, unusual personality, and knack for self-promotion made him perhaps the world's best-known self-taught American folk artist. Finster famously referred to himself as a "stranger from another world," and as the "second Noah" with a divine, prophetic mandate to evangelize the lost. ${ }^{30}$ Finster's self-aggrandizement and general weirdness caught the attention of the artworld. His mission is summed up nicely as painted text in his 1978 piece I am Howard Finster a Stranger from Another World. It states,
I AM HOWARD FINSTER A STRANGER
FROM ANOTHER WORLD. MY FATHER
AND MOTHER. MY SISTERS AND BROTHER
MY WIFE. MY CHILDRE [sic] MY GRAND CHILDREN
HAVE REALLY NEVER FIGURED ME OUT
FOR MY KINGDOM IS NOT OF THIS WORLD
ONLY MY FATHE [sic] IN HEAVEN KNOWS ME
ON THIS PLANET AND THAT'S WHY I HAVE
BEEN STRONG AND HAPPY, WHEN MY WORK
IS FINISHED I WILL GO BACK TO OTHER WORLDS ${ }^{31}$

While many of his theological ideas were typical for southern evangelicalism, Finster's theology was idiosyncratic in particular areas. For instance, although eschatology is very important for Finster, he devised his own brand of a millennialism instead of grasping onto a premillennial dispensationalism. He also devised his own ideas of outer space due to a conviction that God will use planets in the eschaton. ${ }^{32}$ His southern heritage, evangelical theological commitments, and craft traditions sourced his visionary work. Because of his mystical roots, Finster was labeled a visionary artist, but also as a "grassroots, vernacular, self-taught, marginal, and outsider artist." ${ }^{33}$ Because of some of his maverick beliefs, it is difficult to pinpoint Finster's denominational affiliation. Finster was a Southern Baptist minister yet depicts a sort of charismatic faith with a focus on the works of the Holy Spirit. Folk artist Myrtice West tellingly distinguishes herself from Finster in an interview with Greg Bottoms:

"If you want to know the difference between me and Howard," West says, "it's that Howard was always trying to help the sinner. He wanted to forgive people. There was people around here all the time, laughing and carrying on, lots of

\footnotetext{
${ }^{29}$ Matilsky, 14.

${ }^{30}$ Carol Crown, "Howard Finster," in Coming Home!: Self-Taught Artists, the Bible and the American South, Carol Crown, Ed. (Jackson: University Press of Mississippi, 2004), 31.

31 Howard Finster, I am Howard Finster a Stranger from Another World, 1978.

32 Norman Girardot, Envisioning Howard Finster: The Religion and Art of a Stranger from Another World (Oakland: University of California Press, 2015), 81.

33 Girardot, Envisioning Howard Finster, 31.
} 
them sinners. Howard wanted people to find God and love each other and be happy. I reckon that was the Southern Baptist in him.” "So what about you,” I ask. I clicked off the tape recorder. "What’s your message?” "My message.” She looks out the front window; a huge flock of black birds sits in a tall, naked tree above a small, gray house with dead leaves in the yard. "My message is that this is the end. I saw Jesus in that Holiness Church. His hands were braided together, held up over his head, like this here, and in between his fingers, in the light, was a message about the Jews and the end of the world. ${ }^{34}$

So for West, Finster's Southern Baptist orthopraxis was evident in his concern for conversions, whereas her Holiness predilection was shown through eschatological imagery. Both, however, dealt with eschatology in their art. The difference, it seems, is that Finster was more pastorally focused on the individual person, whereas West was striving to obediently portray her Lord's message.

The main theological point expressed in Finster's art was always transformation. Along with creating new paintings, Finster would take, restore, and repurpose found objects. In this way, his very act of creation becomes a performance of re-creation. His "method" was as much a work of art as the artifacts that he produced. This process points towards Finster's eschatological commitments, dealing with and confronting brokenness of the human condition. On his method, Girardot writes, "He and his healing art constitute a sign of how a meaningful world may be re-created out of millions and millions of broken shards." 35 Girardot calls this "religion as art" rather than merely "religion using art," because the process of translating visions and dreams into words and images is both an artistic and a religious endeavor. ${ }^{36}$

It should be noted, however, that while Finster's aim was often to proselytize through his art, he did so from a place of comfort even when the messages were direct and reproving. ${ }^{37}$ Finster's famous Paradise Garden, for instance, was intended as a place where everyone is invited to contribute and make art. ${ }^{38}$ Paradise Garden is Finster's museum-like attraction in Summerville, Georgia. It is his legacy, and has become one of Georgia’s greatest attractions, as it is still operational today. Finster said this about the Garden:

I built the park because I was commissioned by God. I started the Garden in 1970 about one hundred feet into the backyard, built a cement walk and put up a haul shed and started to display the inventions of mankind. My park is a memorial to inventors. The inventors don't get recognition. They don't have an Inventor's Day. To represent them, I'm trying to collect at least one of every invention in the world. ${ }^{39}$

Paradise Garden is thus a communal space. This is a location where people from all over, from any walk of life, can come together and create or "invent" something. Weaver claims that Finster's artistic practice is "an invocation to see in our religious experience what before had been unseeable., ${ }^{40}$ Finster has created an invitation for people to come and re-create the world. He generated an eschatological community inviting everyone in, while at the same time unabashedly proclaiming the good news and the seriousness of sin and redemption.

Morgan and Finster share many qualities. They are both considered folk and outsider artists because they are untrained and unfamiliar with the broader artworld (at least their careers began that way). They both display

\footnotetext{
34 Bottoms, The Colorful Apocalypse, 49.

35 Girardot, Envisioning Howard Finster, 61.

${ }^{36}$ Girardot, Envisioning Howard Finster, 13.

37 Crown, "Howard Finster," 31.

${ }^{38}$ Girardot, Envisioning Howard Finster, 18.

39 Howard Finster, Paradise Garden Foundation, http://paradisegardenfoundation.org/history/the-garden/ (accessed 10/3/15).

40 Jann Weaver, "Gary Seal and Outsider Art: Engaging the Sacramental through Prophetic Form,” in Visual Theology: Forming and Transforming the Community through the Arts, Robin Jensen and Kimberly Vrudny, Eds., (Collegeville: Liturgical Press, 2009), 57.
} 
a southern Charismatic faith and are difficult to pinpoint denominationally. They both have eccentric personalities, and both of them began creating art after receiving a divine mandate to do so. They both also worked with eschatological themes and offered stern warnings of impending doom. While they had different reasons to enter the world of visual art, they were each guided by a pneumatological imagination that was steeped in apocalypticism. They share a sense of urgency to form a community that is an eschatological remnant in anticipation of the coming Christ.

\section{Authenticity, Novelty, and Documentation}

After considering the personalities of these artists in juxtaposition with their works, a trend can be discerned. Folk artists rise to fame because of who they are rather than what they create. In this way, the artworld, I believe, recognizes "Howard Finster" or "Sister Gertrude Morgan” as works of art to be examined. It is not any particular work of art that these artists produced, but rather their eccentricities and authentic life-long commitments to work and mission that makes them so intriguing. The folk art aesthetic is not evaluated by formal analysis, but rather an artist's success or failure lies in his or her ability to faithfully express religious and cultural convictions. In other words, the artworks produced by folk artists are testaments of their culture, personalities, and beliefs. Just as galleries and museums display documentation of performance art and process pieces, they also display the documentation of a folk artist's vision.

Roger Cardinal calls an outsider aesthetic as involving "autistic air" compounded with feelings of "participatory bemusement," strangeness, amazement, and wonderment arising from the artist's related yet distinctive obsessiveness. ${ }^{41}$ Cardinal notes that it is difficult to pinpoint visual qualities in all outsider art because the artists are un-trained, making it is impossible to codify any interconnected genesis of their work. ${ }^{42}$ Nevertheless, one can observe recurring features in Outsider Art. Outsider Art portrays a natural human proclivity towards pattern, representation, and labeling. As text is common in Outsider Art, folk art utilizes text in didactic and proclamatory ways. Text in folk art is less decorative and more proselytizing. It may be the case that the juxtaposed images of folk art are there merely to adorn or illustrate the text, which carries the message. Furthermore, the message is not confined to the text, but belongs rather to the artist who functions as the preacher/prophet. The text in Morgan and Finster's work is thus proclamatory and didactic, consisting either of Scriptural passages or prophetic proclamations.

It is not likely the case that the artworld actually cares what these folk artists are saying, but rather that they are saying it as evidence of their personal convictions. Leslie Dill, for instance, was attracted by the power and passion of Morgan's message rather than by the actual tenants of Morgan's Christian beliefs. Dill is religiously devoted to the Buddhist tradition, but was nevertheless enraptured by Morgan's life, ministry, and work. ${ }^{43}$ The artworld approaches the work of folk artists sociologically rather than formally or disinterestedly. The folk artists of the American south reveal something autobiographical, but also something about the religious and cultural sensibilities of the region. The documentation of folk art also allows one to examine the psychological states of the artists.

\footnotetext{
${ }^{41}$ Roger Cardinal, “Toward and Outsider Aesthetics," in the Artist Outsider: Creativity and the Boundaries of Culture, Michael Hall and Eugene Metcalf, Jr., Eds. (Washington: Smithsonian Institution Press, 1994), 33.

42 Cardinal, 33.

43 Matilsky, 14.
} 


\section{Conclusion}

The curious case of charismatic folk art as a legitimate expression of contemporary art can be seen as a case study of the artworld's values in art. The days of formal deliberation in art are long gone and replaced with a contextual and culturally relative deliberation. Art must now be assessed by the merits of its own terms rather than by the terms of a central institution. Unknowingly, folk art has expanded the concept of what art can be in a classificatory sense. Folk art shows that visual art can be art while not necessarily existing for the institution of art. In the same way, folk art can be polemical and didactic while avoiding the penalty of being deemed kitsch.

Integral to folk art is the honest proclamation of the artist's visionary message. As such, it does not matter if folk art portrays signs of kitsch or sentimentality. Nor does it cheapen a work if it is polemical or didactic. In fact, folk art is important for the artworld precisely because it challenges the way art is understood. ${ }^{44}$ Since the formal rules of the modern aesthetic do not apply to folk art, a new mode of deliberation, and, consequently, a broader rule of classification and legitimation has emerged. The novelty of folk art lies in its artists, which supersedes the usual aversions to kitschy didacticism. Thus the defining currency of legitimate folk art is authenticity.

\section{References}

Bottoms, G. (2007). The colorful apocalypse: Journeys in outsider art. Chicago: The University of Chicago Press.

Bottoms, G. (2013). Spiritual American trash: Portraits from the margins of art \& faith. Berkeley: Couterpoint.

Cardinal, R. (1994). Toward and outsider aesthetics. In M. Hall and E. Metcalf, Jr. (Eds.), The artist outsider: Creativity and the boundaries of culture. Washington: Smithsonian Institution Press.

Crown, C. (2004). Howard finster. In C. Crown (Ed.), Coming home!: Self-taught artists, the Bible and the American South. Jackson: University Press of Mississippi.

Crown, C. (2004). The Bible, evangelical Christianity, and southern self-taught artists. In C. Crown (Ed.), Coming home!: Self-taught artists, the Bible and the American South. Jackson: University Press of Mississippi.

Crown, C., \& Charles, R. (2007). Introduction. In C. Crown and C. Russell (Eds.), Sacred and profane: Voice and vision in southern self-taught art. Jackson: University Press of Mississippi.

Crown, C., \& Cheryl, R. (Eds.) (2013). The new encyclopedia of southern culture, Volume 23: Folk art. Chapel Hill: North Carolina Press.

Delacruz, E. M. (2000). Outside in: Deliberation on American contemporary folk art. The Journal of Aesthetic Education, 34, 1, 77-86.

Fagaly, W. (2004). Tools of her ministry: The art of Sister Gertrude Morgan. New York: Rizzoli International Publications.

Finster, H. (1978). I am Howard Finster a stranger from another world.

Finster, H. (1978). Paradise garden foundation. Retrieved 15 March, 2015 from http://paradisegardenfoundation.org/history/the-garden/

Girardot, N. (2015). Envisioning Howard Finster: The religion and art of a stranger from another world. Oakland: University of California Press.

Kuspit, D. (1985). In search of the visionary image. Art Journal, 45, 4, 319-322.

Luebbers, L. (2004). Introduction. In C. Crown (Ed.), Coming home!: Self-taught artists, the Bible and the American south. Jackson: University Press of Mississippi.

Matilsky, B. (2011). Leslie Dill's poetic visions: From Shimmer to Sister Gertrude Morgan. Bellingham: Whatcom Museum.

McQueen, L. (2012). Toward a pentecostal eschatology: Discerning the way forward. Dorset: Deo Publishing.

Peiry, L. (1997). Art brut: The origins of outsider art. Paris: Flammarion.

Rhodes, C. (2000). Outsider art: Spontaneous alternatives. London: Thames \& Hudson.

${ }^{44}$ Elizabeth Manley Delacruz, “Outside In: Deliberation on American Contemporary Folk Art," The Journal of Aesthetic Education, Vol. 34, No. 1 (2000), 84. 
Stephens, R. (2008). The fire spreads: Holiness and pentecostalism in the American south. Cambridge: Harvard University Press. Weaver, J. (2009). Gary seal and outsider art: Engaging the sacramental through prophetic form. In R. Jensen and K. Vrudny (Eds.), Visual theology: Forming and transforming the community through the Arts. Collegeville: Liturgical Press.

Wilson, C. (2004). A larger view: Self-taught art, the Bible, and Southern creativity. In C. Crown (Ed.), Coming home!: Self-taught artists, the Bible and the American south. Jackson: University Press of Mississippi. 